\title{
Immunohistochemistry of the Bovine Secretory Carbonic Anhydrase Isozyme (CA- VI) in Bovine Alimentary Canal and Major Salivary Glands
}

\author{
Misato KASEDA ${ }^{1)}$, Nobutsune ICHIHARA ${ }^{1)}$, Toshiho NISHITA ${ }^{2)}$, Hajime AMASAKI ${ }^{3)}$ and Masao ASARI ${ }^{1)}$ \\ ${ }^{1)}$ Departments of Anatomy, and ${ }^{2)}$ Physiology, School of Veterinary Medicine, Azabu University, 1-17-71 Fuchinobe, Sagamihara-shi, \\ Kanagawa 229-8501 and ${ }^{3)}$ Department of Veterinary Anatomy, Nippon Veterinary and Animal Science University, 1-7-1, Kyonan-cho, \\ Musashino-shi, Tokyo 180-8602, Japan
}

(Received 21 July 2005/Accepted 2 November 2005)

\begin{abstract}
In the present study, we firstly demonstrated immunohistochemical expressions of secretory carbonic anhydrase (CA-VI) isozyme in bovine forestomach, large intestine and major salivary glands. CA-VI was detected in basal layer epithelial cells of esophageal and forestomach stratified epithelium, in mucous cells of upper glandular region of large intestine, in serous acinar cells of the parotid gland, in serous demilune cells and some ductal liner cells of mandibular, monostomatic sublingual and esophageal glands. These immunohistolocalizations suggested that bovine CA-VI plays various roles in $\mathrm{pH}$ regulation, maintenance of ion and fluid balance, and cell proliferation.
\end{abstract}

KEY WORDS: bovine digestive organs, CA-VI, immunohistochemical localization.

J. Vet. Med. Sci. 68(2): 131-135, 2006

Carbonic anhydrase isozyme-VI (CA-VI) is a unique secretory type CA isozyme. It was initially discovered and purified from ovine saliva [7], and then rat saliva [6, 21], human saliva [13, 20, 22, 25] and bovine saliva [5]. Fernley et al. [8] examined sheep CA-VI in 18 different tissues from sheep using biochemical analysis. They observed an immunoreactive signal for CA-VI only in parotid and mandibular glands, which suggested that CA-VI increased buffering capacity in the oral cavity. Some studies have identified the acinar cells of salivary glands as the origin of CA-VI in several species $[5,8,21,22,25]$. These studies have shown that CA-VI was present in acinar cells of the mammalian parotid and mandibular glands, from where CA-VI is secreted into the saliva. However, CA-VI expression in other segments of the alimentary canal has received little information and the precise physiological role of bovine CA-VI has never been revealed. The present study examines the immunohistochemical expression of CA-VI in bovine alimentary canal and in major salivary glands, and conjectures the function of $\mathrm{CA}-\mathrm{VI}$ in the bovine digestive organs.

\section{MATERIALS AND METHODS}

Tissue: Three adult Holstein cows were used in the present study. Small tissue blocks were prepared for microscopic observation. Samples were cut from the parotid, mandibular, and monostomatic sublingual glands, from cervical to thoracic segments of the esophagus, rumen, reticulum, omasum, abomasum, duodenum, jejunum, ileum, cecum, colon and rectum. The samples were immediately fixed in Bouin's solution, and then sliced into $3 \mu \mathrm{m}$-thick sections.

CA-VI antibody: We purified CA-VI from bovine saliva as described previously [5]. A rabbit polyclonal antibody has been raised against purified bovine CA-VI and specific immunity to bovine CA-VI has been confirmed [5]. Briefly, the antibody against purified bovine CA-VI was produced in the rabbit. Rabbits were injected initially with $1 \mathrm{mg}$ of purified CA-VI emulsified with an equal volume of Freund's complete adjuvant, followed by a weekly booster injection of a fixed amount of the enzyme for 5 weeks. The rabbits were bled via the auricular vein 10 days following the last injection. The specificity of the antiserum was confirmed by the double immunodiffusion method (data not shown).

Immunohistochemical staining: Deparaffinized and rehydrated sections were pretreated with $0.3 \% \mathrm{H}_{2} \mathrm{O}_{2}$ in methanol to block endogenous peroxidase activity, and with normal goat serum (2\% in PBS) for 20 min to block non-immunospecific fragment. For the primary reaction, monospecific antisera against the CA-VI isozymes [5], diluted at 1:2,000, were used for histological localization of the respective isozymes. Following incubation in antiserum for $1 \mathrm{hr}$ at $37^{\circ} \mathrm{C}$, immuno-positive reactions were visualized by the Vectastain Elite avidin-biotin-peroxidase complex and diaminobenzidine (ABC-POD reagent kit; Vector, Burlingame, CA, U.S.A.). The staining procedure was performed according to the manufacturer's protocol. All preparations were incubated with $0.02 \% \mathrm{H}_{2} \mathrm{O}_{2}$ and $0.1 \%$ diaminobenzidine tetrahydrochloride in $0.05 \mathrm{M}$ Tris- $\mathrm{HCl}(\mathrm{pH}$ 7.6) for 5 min. Fixation with Bouin's fluids has been found to provide the maximum retention of affinity for the present antibody and the most consistent immunostaining by the previous studies [5].

Western blotting: Ten \% dodecyl sodium sulfate polyacrylamide gel electrophoresis (SDS-PAGE) was applied in the analyzing of crude extracts from bovine tissues. Briefly, $10 \mu \mathrm{l}$ samples from crude extracts of bovine colon, rumen and parotid gland, and low-molecular-weight protein marker (Pharmacia, Piscataway, NJ, U.S.A.) were directly boiled in $100 \mu \mathrm{l}$ SDS-PAGE sample solvent with mercaptoethanol at $100^{\circ} \mathrm{C}$ for $5 \mathrm{~min}$. Then, samples were submitted to $10 \%$ SDS-PAGE, and the gel was electroblotted onto 
immobilon PVDF transfer membranes (Millipore, Bedford, MA, U.S.A.). The PVDF membrane was stained with antibovine CA-VI serum by the indirect immunoreactive method according to a previous report [5].

\section{RESULTS}

The immunohistochemical results are summarized in Tables 1 and 2. CA-VI was detected at serous acinar cells in parotid glands (Fig. 1), and at serous demilunes cells and some heterogeneous immunopositive pattern of salivary ductal cells in mandibular and sublingual glands (Fig. 2). In these glands, no CA-VI was detected at mucous acinar cells. In the alimentary canal, CA-VI was detected in serous demilune cells and ductal epithelial cells of esophageal glands (Fig. 3), and in stratified squamous epithelial cells at the lower region of the esophageal and forestomach epithelium (Figs. 4, 5). The immunoreaction in the forestomach epithelium was stronger than in the esophageal epithelium. CAVI immunoreactions were weak or absent from abomasal and small intestine glandular cells, although epithelial cells at the upper region of the large intestinal glands in the cecum, colon, and rectum were strongly immuno-positive (Fig. 6).

A single immunoreacted band with about $42 \mathrm{kD}$ was clearly detected in crude extracts from bovine colon, rumen and parotid gland samples on a western blotted PVDF membrane after 10\% SDS-PAGE (Fig. 7).

\section{DISCUSSION}

CA-VI is a unique secretory type isozyme that was discovered in the ovine parotid gland and saliva [7]. It was firstly purified by Feldstein and Silverman [6] from rat saliva, and later by Murakami and Sly [20], Kadoya et al. [13], and Parkkila et al. [25] from human, and Asari et al. [5] from bovine saliva. Previous immunohistochemical analysis has demonstrated the cellular and intracellular origins of CA-VI in the parotid and mandibular glands of humans, mice, rats, and sheep [8, 24, 25, 27], in developing parotid glands of cattle [5], in the lacrimal gland of rat [23], and in the lingual serous von Ebner's glands of humans, rats [18], and mice [2]. CA-VI has been detected in bovine mammary gland $[11,16]$ and in rat lower airways and lung $[18,19]$.

Fernley et al. [8] and Kitade et al. [15] have examined biochemical expressions of CA-VI in digestive organs of sheep and bovine calves. They found that CA-VI was confined entirely to the salivary gland, specifically the parotid and mandibular salivary glands. However, our present study firstly revealed the distributions of bovine CA-VI in alimentary canals by the immunohistochemical and western blotting analysis. Western blotting analysis utilizing histological specimens as the source of antigens clearly demonstrates crossreactivity of this serum with the crude extracts from present bovine samples. The molecular weight of the substance recognized by this serum coincided well with the reported mass of $42 \mathrm{kD}$ for the bovine CA-VI [5]. The positive band of rumen was weaker than others in the western blotting analysis. A number of immunopositive cells of rumen were less than the other portion in the immunohistochemical analysis. We confirmed bovine CA-VI not only in the acinar and demilune cells of the parotid, mandibular and sublingual glands, but also in the stratified epithelial cells of the basal region of stratified squamous epithelium in esophagus and forestomach, and also in the mucous cells of the upper region of intestinal glands in large intestine.

The secretion of CA-VI from saliva and esophageal

Table 1. Immunohistochemical distribution of the CA isozyme CA-VI in the bovine major salivary glands

\begin{tabular}{lcccc}
\hline & $\begin{array}{c}\text { Serous } \\
\text { acinar cell }\end{array}$ & $\begin{array}{c}\text { Mucous } \\
\text { acinarcell }\end{array}$ & $\begin{array}{c}\text { Striated } \\
\text { ductcell }\end{array}$ & $\begin{array}{c}\text { Interlobular } \\
\text { ductcell }\end{array}$ \\
\hline Parotid glands & ++ & $\mathrm{Ab}^{\mathrm{b})}$ & - & - \\
Mandibular glands & $++^{\mathrm{a})}$ & - & $++^{\mathrm{c})}$ & $++^{\mathrm{c})}$ \\
Monostomatic sublingual glands & $++^{\mathrm{a})}$ & - & $++^{\mathrm{c}}$ & $++^{\mathrm{c})}$ \\
\hline
\end{tabular}

a) Serous demilune.

b) Absent.

c) Heterogeneous immunopositive patterned cells.

Table 2. Immunohistochemical distribution of the CA isozyme CA-VI in the bovine alimentary canal

\begin{tabular}{|c|c|c|c|c|c|c|c|c|c|c|c|}
\hline & \multicolumn{5}{|c|}{ Forestomach } & \multicolumn{2}{|c|}{ Small intestine } & \multicolumn{4}{|c|}{ Large intestine } \\
\hline & Esophagus & Rumen & Reticulum & Omasum & Abomasum & Duodenum & Jejunum & Ileum & Cecum & Colon & Rectum \\
\hline $\begin{array}{l}\text { Tegmental epithelium } \\
\text { Glanular epithelium }\end{array}$ & 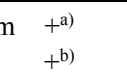 & $++^{a)}$ & $\begin{array}{l}++^{a)} \\
-\end{array}$ & $++^{a)}$ & Trace $^{\mathrm{c})}$ & Trace & Trace & Trace & $\left.++^{d}\right)$ & $++^{\text {d) }}$ & $++^{d)}$ \\
\hline
\end{tabular}

a) Lower region of stratified epithelium.

b) Serous demilune and duct liner cells (Mucous acinar cell is negative reaction to CA-VI antibody.).

c) All type of gastric gland cells.

d) Upper region of intestinal glands. 

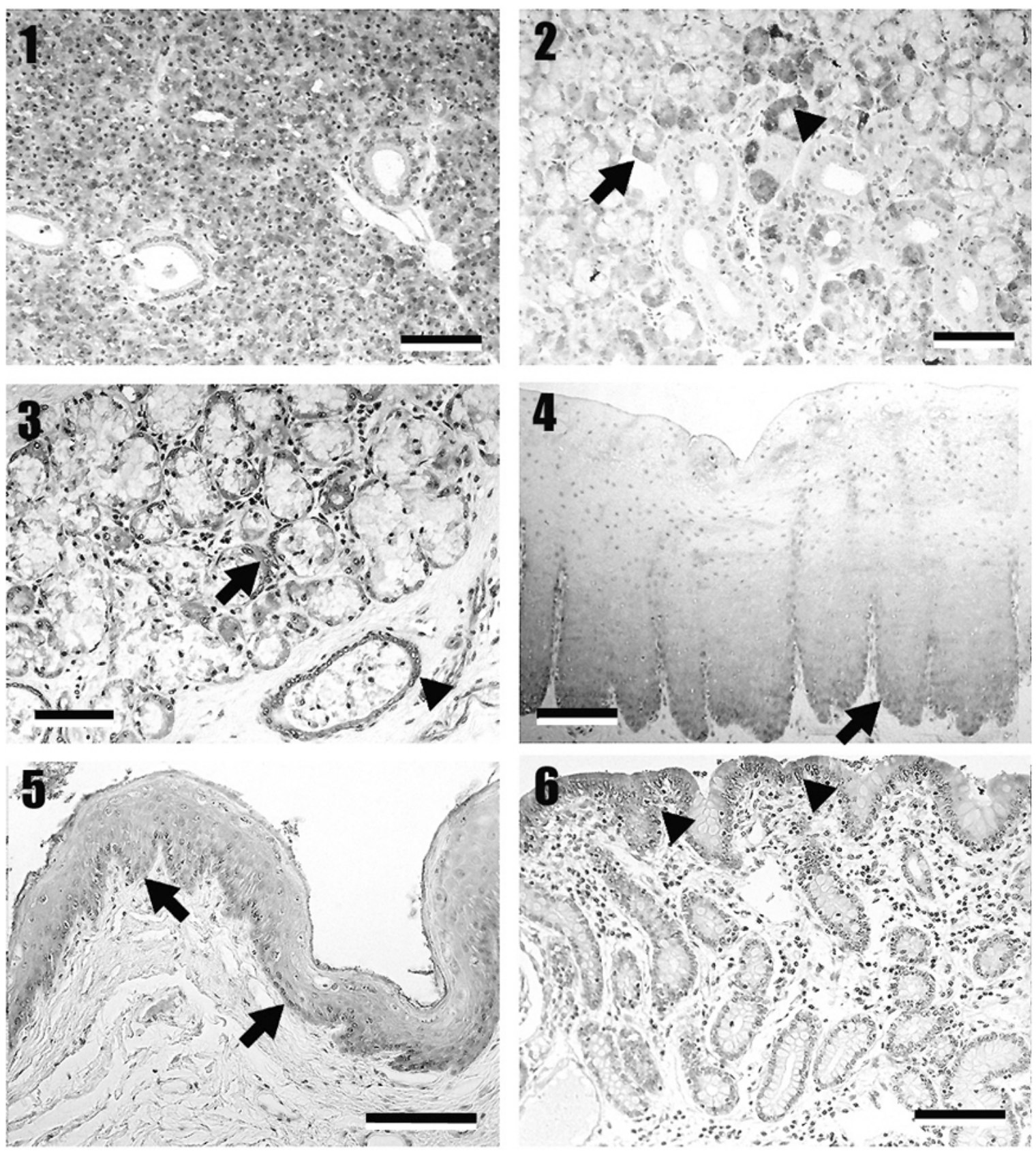

Fig. 1. Immunoreactivity to the anti-bovine CA-VI antibody in the parotid glands. CA-VI was detected at the serous acinar cells. Bar: $50 \mu \mathrm{m}$.

Fig. 2. Immunoreactivity to the anti-bovine CA-VI antibody in the mandibular glands. The serous demilune cells (arrow) and some heterogeneous immunopositive patterned cells of duct (arrowhead) were positive to the anti-bovine CA-VI antibody. Bar: $50 \mu \mathrm{m}$.

Fig. 3. Immunoreactivity to the anti-bovine CA-VI antibody in the esophagus. CA-VI was detected at the serous demilune cells (arrow) and the ductal epithelial cells (arrowhead) of the esophageal glands. Bar: $100 \mu \mathrm{m}$.

Fig. 4. Immunoreactivity to the anti-bovine CA-VI antibody in the esophagus. Arrow shows that the anti-bovine CA-VI was detected at the stratified squamous epithelial cells at the lower region of the esophageal epithelium. Bar: $100 \mu \mathrm{m}$.

Fig. 5. Immunoreactivity to the anti-bovine CA-VI antibody in the rumen. Arrows show that the anti-bovine CA-VI was detected at the stratified squamous epithelial cells at the lower region of the ruminal epithelium. Bar: $100 \mu \mathrm{m}$.

Fig. 6. Immunoreactivity to the anti-bovine CA-VI antibody in the colon. Arrowheads show that the epithelial cells at the upper region of the colon were indicated strong positive immunoreactions against the anti-bovine CA-VI antibody. Bar: $100 \mu \mathrm{m}$. 


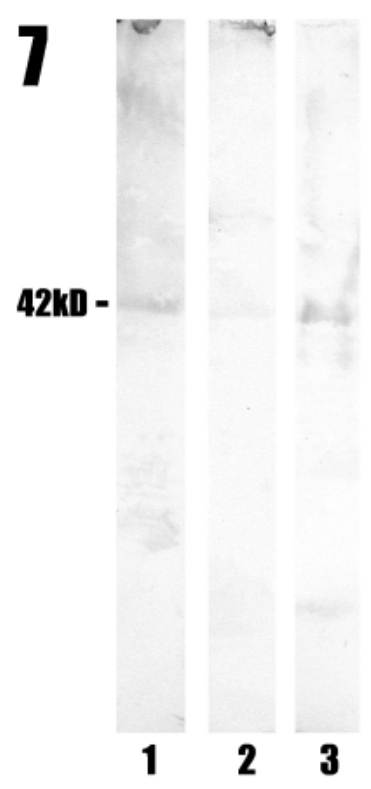

Fig. 7. Western blotting of the crude extracts from bovine colon, rumen and parotid gland samples after $10 \%$ SDS-PAGE. Lane 1: colon crude extract. Lane 2: rumen crude extract. Lane 3: parotid gland crude extract. Note: a single band is detected at about $42 \mathrm{kD}$.

secretions might be useful for the maintenance of $\mathrm{pH}$ balance at the upper alimental canal from the mouth to the rumen. With regard to the cytosolic CA isozymes, Asari et al. [4] have already investigated well-known CA isozymes (CA-I, CA-II and CA-III) in bovine salivary glands and alimentary canal. The secretory CA-VI accelerates the neutralization of excess organic acids produced by microbial flora on dental and epithelial surfaces in the oral cavity and it forms a mutually complementary system with cytosolic $\mathrm{CA}$ for $\mathrm{pH}$ regulation in the upper alimentary canal $[17,26]$. $\mathrm{CA}-\mathrm{VI}$ may be used for the control of $\mathrm{pH}$ and ion balance at the ruminant upper digestive tract in association with other CA isozymes.

CA-VI is also found in various mammalian tissues, such as uterus, prostate and mammary glands in man, mouse, rat, hamster, guinea pig, cow, and horse [12, 28-30]. Expression of CA-VI in the bovine stratified epithelial cells at the basal layer in esophagus and forestomach stratified epithelium might assist cytosolic CA isozymes in the absorption of VFAs and ammonia. CA isoenzymes play an important role in the hydration of $\mathrm{CO}_{2}$ to provide a continuous source of $\mathrm{H}^{+}$to the lumen and cytoplasm for the transport of VFAs [3]. Additionally, this expression of CA-VI might enhance cell proliferation in the stratified squamous epithelium. During developmental periods, basal layer cells in the bovine ruminal epithelium react to members of the $\mathrm{CA}$ isozyme family such as CA-III [1], which is believed to control ruminal epithelial development. Henkin et al. [9, 10] and Karhumaa et al. [14] also reported that CA isozymes have a multifunctional protein like growth factor. Cytosolic CA might play a role in VFA absorption from the forestomach epithelium and epithelial cell proliferation by controlling the ionic milieu and maintenance of $\mathrm{HCO}_{3}{ }^{-}$. This concept is supported by our observation that the immunoreaction to CA-VI was higher in the forestomach epithelium than in the esophagus.

CA-VI was detected in epithelial cells in the upper region of the small and large intestinal glands in addition to CA-II expression [28]. At the small intestinal epithelium, immunoreaction against $\mathrm{CA}-\mathrm{VI}$ was slight, which suggests that the small intestine may utilize CA-VI for the absorption of amino acids and other nutrient components. The strong expression in the large intestine may control heavy water metabolism and ion exchange. These results are the first to demonstrate the expression of CA-VI in the ruminant alimentary canals and suggest that CA-VI might be a multifunctional protein in bovine ruminant digestive organs.

\section{REFERENCES}

1. Amasaki, H., Matsumoto, S. and Daigo, M. 1991. Distributions of fibronectin, laminin, type I and IV collagens and carbonic anhydrase isozymed III during bovine ruminal epithelial develop. Acta Anat. 140: 169-174.

2. Amasaki, H., Arai, R., Ogawa, M., Takemura, N., Yamagami, T., Nagasao, J., Mutho, K., Ichihara, N. and Asari, M. 2003. Postnatal development of the mouse volatile papilla taste bud cells. J. Vet. Med. Sci. 65: 541-543.

3. Argenzio, R.A. 1984. Introduction to Gastrointestinal. pp. 290310. In: Duke's Physiology of Domestic Animals. Digestion, Absorption and Metabolism Function (edited by SWENSON, M.J.).

4. Asari, M., Sasaki, K., Kano, Y. and Nishita, T. 1989. Immunohistochemical localization of carbonic anhydrase isozymes I, II and III in the bovine salivary glands and stomach. Arch. Histol. Cytol. 52: 337-344.

5. Asari, M., Miura, K., Ichihara, N., Nishita, T. and Amasaki, H. 2000. Distribution of carbonic anhydrase isozyme VI in the developing bovine parotid gland. Cells Tissues Organs 167: $18-24$.

6. Feldstein, J.B. and Silverman, D.N. 1984. Purification and characterization of carbonic anhydrase from the saliva of the rat. J. Biol. Chem. 259: 5447-5453.

7. Fernley, R.T., Wright, R.D. and Coghlan, J.P. 1979. A novel carbonic anhydrase from the ovine parotid gland. FEBS Lett. 105: 299-302.

8. Fernley, R.T., Darling, P., Aldred, P., Weight, R.D. and Coghlan, J.P. 1989. Tissue and species distribution of the secreted carbonic anhydrase isozyme. Biochem. J. 259: 91-96.

9. Henkin, R.I., Martin, B.M. and Agarwal, R.P. 1999a. Decreased parotid saliva gustin/carbonic anhydrase VI secretion: an enzyme disorder manifested by gustatory and olfactory dysfunction. Am. J. Med. Sci. 318: 380-391.

10. Henkin, R.I., Martin, B.M. and Agarwal, R.P. 1999b. Efficacy of exogenous oral zinc in treatment of patients with carbonic anhydrase VI deficiency. Am. J. Med. Sci. 318: 392-404.

11. Ichihara, N., Asari, M., Kasuya, T., Susaki, E., Matsui, K., Nishita, T. and Amasaki, H. 2003. Immunohistolocalization of carbonic anhydrase isozyme (CA-VI) in bovine mammary glands. J. Vet. Med. Sci. 65: 1167-1170. 
12. Igarashi, S., Kano, Y., Nishita, T., Amasaki, H. and Aasari, M. 1992. Comparison of the distribution of carbonic anhydrase isozymes (CA-I, CA-II, CA-III) in the rat gastrointestinal tract. J. Vet. Med. Sci. 54: 535-539.

13. Kadoya, Y. T., Kuwahara, H., Shimazaki, M., Ogawa, Y. and Yagi, T. 1987. Isolation of a novel carbonic anhydrase from human saliva and immunohistochemical demonstration of its related isozymes in salivary gland. Oosaka City Med. J. 33: 99-109.

14. Karhumaa, P., Leinonen, J., Pakkila, S., Kaunisto, K., Tapanainen, J. and Rajaniemi, H. 2001. The identification of secreted carbonic anhydrase VI as a constitutive glycoprotein of human and rat milk. Proc. Natl. Acad. Sci. U.S.A. 98: 11604-11608.

15. Kitade, K., Takahashi, K., Yonekura, S., Katsumata, N., Furukawa, G., Ohsuga, S., Nishita, T., Katoh, K. and Obara, Y. 2002. Effects of nutritional conditions around weaning on carbonic anhydrase activity in the parotid gland and ruminal and abomasal epithelia of Holstein calves. J. Comp. Physiol. B 172: 379-385.

16. Kitade, K., Nishita, T., Yamato, M., Sakamoto, K., Hagino, A., Katoh, K. and Obara, Y. 2003. Expression and localization of carbonic anhydrase in bovine mammary gland and secretion in milk. Comp. Biochem. Physiol. A Mol. Integr. Physiol. 134: 349-354.

17. Leinonen, J., Kivela, J., Parkkila, S., Parkkila, A.K. and Rajaniemi, H. 1999. Salivary carbonic anhydrase isoenzyme VI is located in the human enamel pellicle. Caris. Res. 33: 185-190.

18. Leinonen, J., Parkkila, S., Kaunisto, K., Koivunen, P. and Rajaniemi, H. 2001. Secretion of carbonic anhydrase isoenzyme VI (CA-VI) from human and rat lingual serous von Ebner's glands. J. Histochem. Cytochem. 49: 657-662.

19. Leinonen, J.S., Saari, K.A., Seppanen, J.M., Myllyla, H.M. and Rajaniemi, H.J. 2004. Immunohistochemical demonstration of carbonic anhydrase isoenzyme VI (CA-VI) expression in rat lower airways and lung. J. Histochem. Cytochem. 52: 11071112.

20. Murakami, H. and Sly, W.S. 1987. Purification and characterization of human salivary carbonic anhydrase. J. Biol. Chem. 262: $1382-1388$.

21. Ogawa, Y., Chang, C.K., Kuwahara, H., Hong, S.S., Toyosawa, S. and Yagi, T. 1992. Immunoelection microscopy of carbonic anhydrase isozyme VI in rat submandibular gland: Comparison with isozymes I and II. J. Histiochem. Cytochem. 40: $807-817$.

22. Ogawa, Y., Hong, S. S., Toyosawa, S., Kuwahara, H., Shimazaki, M. and Yagi, T. 1993. Immunoelectron microscopy of carbonic anhydrase isozymes VI in human submandibular gland: Comparison with isozymes I and II. J. Histochem. Cytochem. 41: 343-351.

23. Ogawa, Y., Toyosawa, S., Inagaki, T., Hong, S.S. and Ijuhin, N. 1995. Carbonic anhydrase isozyme VI in rat lacrimal gland. Histochem. Cell Biol. 103: 387-394.

24. Ogawa, Y., Fernley, R.T., Ito, R. and Ijuhin, N. 1998. Immunohistochemistry of carbonic anhydrase isozymes VI and II during development of the rat salivary glands. Histochem. Cell Biol. 110: 81-88.

25. Parkkila, S., Kaunisto, K., Rajaniemi, L., Kumpulainen, T., Jokinen, K. and Rajaniemi, H. 1990. Immunohistochemical localization of carbonic anhydrase isozymes VI, II, and I in human parotid and submandibular glands. J. Histochem. Cytochem. 38: 941-947.

26. Parkkila, S., Parkkila, A.K., Lehtola, J., Reinila, A., Sodervik, H.J., Rannisto, M. and Rajaniemi, H. 1997. Salivary carbonic anhydrase protects gastroesophageal mucosa from acid injury. Dig. Dis. Sci. 42: 1013-1019.

27. Penschow, J.D., Giles, M.E., Coghlan, J.P. and Fernley, R.T. 1997. Redistribution of carbonic anhydrase VI expression from ducts to acini during development of ovine parotid and submandibular glands. Histochem.Cell Biol. 107: 417-422.

28. Sasaki, K., Igarashi, S., Amasaki, T., Amasaki, H., Nishita, T., Kano, Y. and Asari, M. 1993. Comparative immunohistolocalization of carbonic anhydrase isozymes I, II and III in the equine and bovine digestive tract. Histochem. J. 25: 304-311.

29. Spicer, S.S., Stoward, P.J. and Tashian, R.E. 1979. The immunohistolocalization of carbonic anhydrase in rodent tissue. $J$. Histochem. Cytochem. 27: 820-831.

30. Spicer, S.S., Ge, Z.H., Tashian, R.E., Hazen-Martin, D.J. and Schultz, B.A. 1990. Comparative distribution of carbonic anhydrase isozymes III and II in rodent tissues. Am. J. Anat. 187: 55-64.

31. Tashian, R.E. 1989. The carbonic anhydrase: Widening perspectives on their evolution, expression and function. BioAssays 10: 182-192. 